\title{
Evaluation of an immunodot test to manage white spot syndrome virus (WSSV) during cultivation of the giant tiger shrimp Penaeus monodon
}

\author{
Rajreddy Patil ${ }^{1}$, K. J. Palaksha ${ }^{1}$, T. M. Anil ${ }^{1}$, Guruchannabasavanna ${ }^{1}$, Prakash Patil ${ }^{1}$, \\ K. M. Shankar ${ }^{1, *}$, C. V. Mohan ${ }^{1}$, A. Sripada ${ }^{2}$ \\ ${ }^{1}$ Fish Pathology and Biotechnology Laboratory, Department of Aquaculture, College of Fisheries, Karnataka Veterinary, \\ Animal and Fisheries Sciences University, Mangalore 575 002, India \\ ${ }^{2}$ Biological Oceanography Division, National Institute of Oceanography, Dona Paula 403 004, India
}

\begin{abstract}
A monoclonal antibody-based immunodot test was compared to a polymerase chain reaction (PCR) assay for managing white spot syndrome virus (WSSV) on shrimp farms at Kundapur and Kumta situated in Udupi and Uttar Kannada Districts, respectively, of Karnataka on the west coast of India. Of 12 grow-out farms in Kundapur, 6 (F1 to F6) yielded shrimp samples that were negative for WSSV by both immunodot test and 1-step PCR from stocking to successful harvest. Samples from the other 6 farms (F7 to F12) were positive for WSSV by both immunodot test and 1-step PCR at various times post stocking, and their crops failed. In the 2 farms at Kumta (F13, F14), immunodot and 1-step PCR results were both negative, and harvests were successful. In contrast to 1-step PCR results, farms F5, F6, F13, and F14 gave positive results for WSSV by 2-step PCR, and they were successfully harvested at $105 \mathrm{~d}$ post stocking. Our results indicate that an inexpensive immunodot assay can be used to replace the more expensive 1-step PCR assay for disease monitoring.
\end{abstract}

KEY WORDS: Penaeus monodon - WSSV - White spot syndrome virus · Monoclonal antibody · Immunodot assay $\cdot$ PCR $\cdot$ Polymerase chain reaction

\section{INTRODUCTION}

White spot syndrome virus (WSSV, genus Whispovirus, family Nimaviridae; ICTVdB Management 2006) frequently causes high mortalities and near total loss of farmed shrimp crops (Lightner \& Redman 1998). The virus is highly pathogenic to penaeid shrimp and also infects a wide variety of other crustaceans, including marine crabs, copepods, freshwater crabs, and prawns (Lo et al. 1996a, Flegel 1997).

Monoclonal antibody (MAb) based assays developed for detection of WSSV include immunoperoxidase and whole-mount tissue assays (Poulos et al. 2001), immunofluorescence assay (Shih et al. 2001), immunodot assay (Anil et al. 2002), dot-immunogold filtration
(DIGF) assay (Wang et al. 2006), a single-step immunochromatographic test (Wang \& Zhan 2006), and a Shrimple ${ }^{\circledR}$ test strip (EnBioTec Laboratories). Among the various DNA- and antibody-based assays for WSSV, PCR is very sensitive and is used widely for WSSV screening in shrimp hatcheries and grow-out ponds. However, PCR is expensive, sophisticated, and beyond the reach of many farmers for routine, fieldlevel screening of shrimp for WSSV. Thus, Anil et al. (2002) developed a simple MAb-based immunodot assay having sensitivity equal to that of 1-step PCR for detection of WSSV. Here we report the evaluation and comparison of the MAb-based immunodot test to PCR as a screening tool for WSSV in Penaeus monodon grow-out farms. 


\section{MATERIALS AND METHODS}

Immunodot test. Immunodot tests were carried out according to Anil et al. (2002) with a few modifications. Briefly, whole post larvae (PL) or target organs from juvenile shrimp (gills or pleopods) were ground to a fine paste using a mortar and pestle and diluted $(1: 10 \mathrm{w} / \mathrm{v})$ with TNE buffer (0.02 M Tris buffer, $0.4 \mathrm{M} \mathrm{NaCl}, 0.02 \mathrm{M}$ disodium EDTA, $\mathrm{pH}$ 7.4). The homogenate was stored at room temperature for $30 \mathrm{~min}$ to allow larger tissue particles to settle. The clear supernatant $(2 \mu \mathrm{l})$ from the tissue homogenate was dotted onto a $0.2 \mu \mathrm{m}$ nitrocellulose membrane (BioRad) and air-dried for $5 \mathrm{~min}$. The membrane was blocked with $6 \%(\mathrm{w} / \mathrm{v})$ defatted casein in PBS (pH 7.4) for $30 \mathrm{~min}$ and washed thoroughly with wash buffer (PBS supplemented with $0.05 \%$ Tween-20). The membrane was incubated for $1 \mathrm{~h}$ with 1 -wk-old cell culture supernatant from a mouse monoclonal hybridoma clone secreting antibody (IgG2a) specifically reacting with epitopes on VP28 and 18 of WSSV envelope proteins (Anil et al. 2002) and then washed 3 times with wash buffer before treatment for $20 \mathrm{~min}$ with rabbit antimouse IgG peroxidase conjugate (Sigma) diluted 1:2000 in $3 \%(\mathrm{w} / \mathrm{v})$ BSA-PBS. The membrane was washed thoroughly 3 times with wash buffer, treated with 4-chloro-1-napthol solution (Pierce) for $5 \mathrm{~min}$, air-dried, and observed for development of purple-blue dots.
Polymerase chain reaction (PCR). PCR was performed according to Lo et al. (1996b) with modifications in sample preparation and target DNA amplification cycles (Thakur et al. 2002). PCR products were analyzed by $1.5 \%$ agarose gel electrophoresis, with purified WSSV DNA as the positive control and an appropriate negative control without WSSV DNA. No internal control was used in this PCR protocol. Samples that were only 1-step PCR negative were subjected to 2-step PCR.

Evaluation of the immunodot assay for WSSV screening in grow-out ponds. The study was carried out at 2 locations: Kundapur and Kumta situated in Udupi and Uttar Kannada Districts, respectively, of Karnataka on the west coast of India.

Twelve farms in Kundapur ranging from 0.5 to 1.5 ha were chosen for the study from September 2001 to February 2002. These farms were stocked by farmers with apparently healthy post larvae 16 to $20 \mathrm{~d}$ old of Penaeus monodon purchased from different commercial hatcheries. The farms were stocked at different times at densities of 5 to $6 \mathrm{PL} \mathrm{m}{ }^{-2}$. From each farm, 30 PL were collected at the time of stocking, and 15 each were subjected to immunodot and PCR assays. Subsequent sampling was done from $30 \mathrm{~d}$ post stocking (DPS) at $15 \mathrm{~d}$ intervals until either emergency harvest or normal successful harvest at $\geq 100$ DPS. Each sample consisted

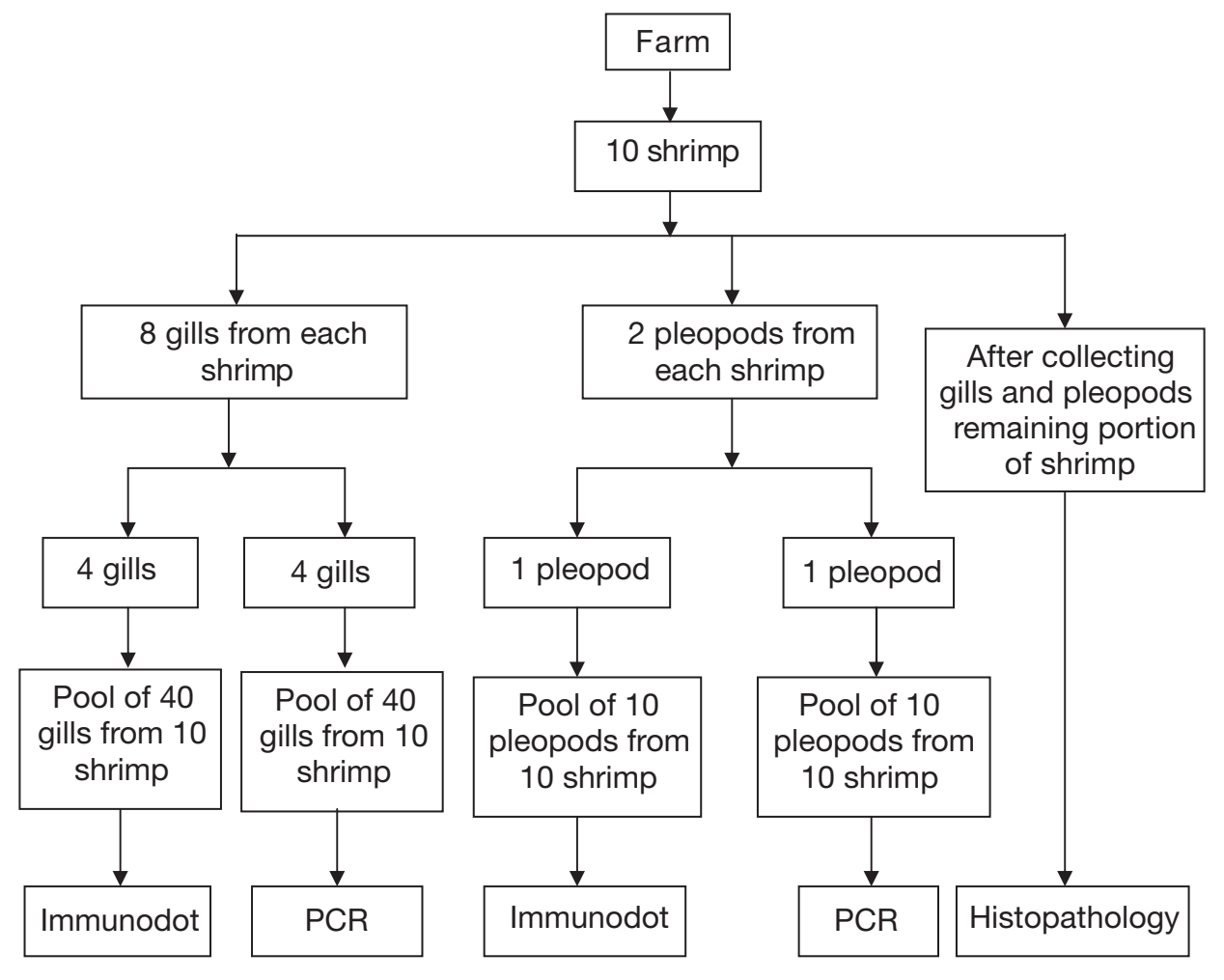

Fig. 1. Sample collection from grow-out farms for immunodot, PCR, and histopathological analyses 
of 10 shrimp randomly collected from the check tray. From each shrimp, 8 gills and 2 pleopods were collected (Fig. 1). The total 80 gills and 20 pleopods were divided into 40 gills and 10 pleopods each for the immunodot test and PCR. PCR samples were fixed in absolute methanol at the farm site, whereas immunodot samples were brought to the laboratory on ice and stored at $-10^{\circ} \mathrm{C}$ for further analysis. After collecting pleopods and gills for PCR and immunodot test, the remainder of the shrimp samples were fixed in $10 \%$ buffered formalin so that histopathological analysis could be carried out following standard procedures.

Two farms in Kumta were chosen for study from September 2003 to November 2004. Shrimp samples were collected as described for Kundapur (Fig. 1).

\section{RESULTS}

\section{Evaluation of immunodot test to screen shrimp for WSSV in grow-out farms}

Initial PL samples for stocking of the 12 farms in Kundapur were found to be WSSV negative when tested by 2-step PCR (Lo et al. 1996b). In 6 farms (F1 to F6), shrimp were negative by immunodot test and 1-step PCR from stocking to 105 DPS, and successful crops were obtained at these farms (Table 1). Shrimp samples from the other 6 farms (F7 to F12) were positive by immunodot test and 1-step PCR at various DPS, and crops failed at these farms with persistent mortality between 75 and 105 DPS. In farms F5 and F6, there

Table 1. Evaluation of immunodot assay and PCR for detection and monitoring of WSSV in shrimp grow-out farms. +: positive result; -: negative result; SNA: sample not available; ND: not done; E: emergency harvest

\begin{tabular}{|c|c|c|c|c|c|c|c|c|c|c|c|}
\hline \multirow{3}{*}{$\begin{array}{l}\begin{array}{l}\text { Location } \\
\text { of farm }\end{array} \\
\text { Kundapur }\end{array}$} & \multirow{3}{*}{$\begin{array}{c}\begin{array}{c}\text { Farm } \\
\text { no. }\end{array} \\
\text { F1-F4 }\end{array}$} & \multirow{2}{*}{\multicolumn{2}{|c|}{$\begin{array}{l}\text { WSSV detection } \\
\text { method }\end{array}$}} & \multicolumn{7}{|c|}{ Days of culture \& results } & \multirow{3}{*}{$\begin{array}{c}\begin{array}{c}\text { Farm harvesting } \\
\text { status }\end{array} \\
\text { Successful }\end{array}$} \\
\hline & & & & 0 & 30 & 45 & 60 & 75 & 90 & 105 & \\
\hline & & \multirow[t]{2}{*}{ PCR } & 1-step & - & - & - & - & - & - & - & \\
\hline & & & 2-step & - & - & - & - & - & - & - & \\
\hline & & \multicolumn{2}{|c|}{ Immunodot } & - & - & - & - & - & - & - & \\
\hline & F5 & PCR & 1-step & - & SNA & - & - & - & - & SNA & Successful \\
\hline & & & 2-step & - & + & - & - & - & - & SNA & \\
\hline & & \multicolumn{2}{|c|}{ Immunodot } & - & SNA & - & - & - & - & SNA & \\
\hline & F6 & PCR & 1-step & - & - & - & - & - & - & - & Successful \\
\hline & & & 2-step & - & - & + & - & - & - & - & \\
\hline & & \multicolumn{2}{|c|}{ Immunodot } & - & - & - & - & - & - & - & \\
\hline & F7 & PCR & 1-step & - & SNA & - & - & - & $+{ }^{E}$ & & Emergency \\
\hline & & & 2-step & - & SNA & - & + & + & ND & & \\
\hline & & \multicolumn{2}{|c|}{ Immunodot } & - & SNA & - & - & - & $+{ }^{E}$ & & \\
\hline & F8 & \multirow[t]{2}{*}{ PCR } & 1-step & - & - & - & - & - & $+{ }^{\mathrm{E}}$ & & Emergency \\
\hline & & & 2-step & - & + & - & - & - & ND & & \\
\hline & & \multicolumn{2}{|c|}{ Immunodot } & - & - & - & - & - & $+{ }^{\mathrm{E}}$ & & \\
\hline & F9 & \multirow[t]{2}{*}{ PCR } & 1-step & - & SNA & - & - & $+{ }^{E}$ & & & Emergency \\
\hline & & & 2-step & - & SNA & - & - & ND & & & \\
\hline & & \multicolumn{2}{|c|}{ Immunodot } & - & SNA & - & - & $+{ }^{\mathrm{E}}$ & & & \\
\hline & F10 & \multirow[t]{2}{*}{ PCR } & 1-step & - & SNA & - & - & $+{ }^{E}$ & & & Emergency \\
\hline & & & 2-step & - & SNA & - & - & ND & & & \\
\hline & & \multicolumn{2}{|c|}{ Immunodot } & - & SNA & - & - & $+{ }^{E}$ & & & \\
\hline & F11 & PCR & 1-step & - & - & - & - & - & $+{ }^{E}$ & & Emergency \\
\hline & & & 2-step & - & - & - & + & - & ND & & \\
\hline & & Immuno & & - & - & - & - & - & $+{ }^{E}$ & & \\
\hline & F12 & PCR & 1-step & - & - & - & - & - & $+{ }^{\mathrm{E}}$ & & Emergency \\
\hline & & & 2-step & - & - & - & - & + & ND & & \\
\hline & & \multicolumn{2}{|c|}{ Immunodot } & - & - & - & - & - & $+{ }^{\mathrm{E}}$ & & \\
\hline \multirow[t]{6}{*}{ Kumta } & F13 & PCR & 1-step & - & - & - & - & - & - & SNA & Successful \\
\hline & & & 2-step & - & + & - & + & + & + & SNA & \\
\hline & & \multicolumn{2}{|c|}{ Immunodot } & - & - & - & - & - & - & SNA & \\
\hline & F14 & PCR & 1-step & - & - & - & - & - & - & SNA & Successful \\
\hline & & & 2-step & - & - & - & - & + & + & SNA & \\
\hline & & \multicolumn{2}{|c|}{ Immunodot } & - & - & - & - & - & - & SNA & \\
\hline
\end{tabular}


were no white spot disease outbreaks even though samples were WSSV positive by 2-step PCR at 30 and 45 DPS, respectively. On the other hand, shrimp samples from F8 and F11 were positive by 2-step PCR at 30 and 60 DPS, respectively, and WSSV outbreaks were recorded at 90 DPS after they became 1-step PCR positive. In farms F9 and F10, outbreaks were recorded between 75 and 90 DPS together with 1-step PCR positive results without any prior indication of WSSV infection by 2 -step PCR.

Positive WSSV immunodot test results for pleopods and 1-step PCR results for gills and pleopods from the 12 farms in Kundapur (Table 2) matched the histopathology results in the parallel samples examined. However, in farms F7 and F8, gills were negative in the immunodot assay but positive by 1-step PCR. By contrast, in farm F11, pleopods were positive in the immunodot assay but negative by 1 -step PCR. For F11, histopathology of the pleopods confirmed the WSSV positive results obtained by the immunodot assay.

Immunodot and 1-step PCR results were negative for WSSV in the 2 farms in Kumta (F13 and F14). Although shrimp samples were positive by 2 -step PCR at 30,60 , 75 , and 90 DPS in F13 and at 75 and 90 DPS in F14, successful harvests were obtained at 105 DPS.

Table 2. Results of immunodot, PCR, and histopathology analysis for WSSV using pleopods and gills of shrimp samples. Tests where results for gills and pleopods differed are given as +/- or -/+ (pleopod/gill). Histological analysis was not performed for F13 and F14. +: positive result; -: negative result; ND: not done

\begin{tabular}{|c|c|c|c|c|}
\hline $\begin{array}{l}\text { Farm } \\
\text { no. }\end{array}$ & Immunodot & $\begin{array}{r}P C \\
\text { 1-step }\end{array}$ & PCR & Histopathology \\
\hline $\mathrm{F} 1$ to $\mathrm{F} 4$ & - & - & - & - \\
\hline F5, F6, F13, F14 & - & - & + & - \\
\hline F7 & $+/-$ & + & ND & + \\
\hline F8 & $+/-$ & + & ND & + \\
\hline F9 & + & + & ND & + \\
\hline F10 & + & + & ND & + \\
\hline F11 & + & $-/+$ & + & + \\
\hline F12 & + & + & ND & + \\
\hline
\end{tabular}

Table 3. Determination of epidemiological specificity and sensitivity for the 1-step PCR test using pleopods. Sensitivity was $83 \%$ (5 true positive/6 positive animals); specificity was $100 \%$ (6 true negative/6 negative animals)

\begin{tabular}{|c|c|c|c|}
\hline \multirow[t]{2}{*}{ PCR test results } & \multicolumn{2}{|c|}{ True disease status } & \multirow[t]{2}{*}{ Total } \\
\hline & Positive & Negative & \\
\hline Positive & 5 true positive & 0 false negative & 5 tests positive \\
\hline Negative & 1 false negative & 6 true negative & 7 tests negative \\
\hline Total & 6 positive & 6 negative & 12 \\
\hline
\end{tabular}

\section{Determination of epidemiological sensitivity and specificity of immunodot test and 1-step PCR}

Results obtained from histopathology of gills and pleopods at the time of harvest were used as the standard for a comparative analysis of epidemiological sensitivity and specificity of the immunodot test and 1-step PCR. A model of the analysis of sensitivity and specificity of 1-step PCR using pleopods is given in Table 3. Using pleopods as the WSSV target organ, sensitivity and specificity of the 1-step PCR were 83 and $100 \%$, respectively, whereas immunodot sensitivity (6 true positive/ 6 positive animals) and specificity ( 6 true negative/6 negative animals) were both $100 \%$. By contrast, the sensitivity and specificity for the immunodot assay using gills as target organs were $67 \%$ (4 true positive/ 6 positive animals) and $100 \%$ (6 true negative/6 negative animals), respectively. The corresponding values for 1 -step PCR were both $100 \%$. Thus, pleopods were considered best for detection of WSSV by the immunodot assay.

\section{DISCUSSION}

Due to its rapid spread and broad host range, WSSV continues to inflict serious damage to the shrimp culture industry world wide. A simple field test would be a good alternative to sophisticated tests such as PCR for monitoring WSSV in grow-out ponds. For our 12 grow-out farms at Kundapur, immunodot assay results for WSSV detection matched those for 1-step PCR if both tested tissues were considered. Although PCR is considered a very sensitive technique, it has several disadvantages. Crude homogenates of some shrimp tissues may contain interfering compounds that can lead to false positive or false negative results (Wang et al. 1996, Nunan et al. 2000). The appearance of early 2-step positive results in F5, F6, and F8 at 30, 45, and 30 DPS, respectively, followed by several negative test results may have been examples of 2-step PCR false positives. Similarly, 2-step PCR negative results at 75 DPS in F11 (after an earlier positive result) and at 45 DPS in F13 (after an earlier positive result and prior to 3 later positive results) may be examples of 2-step PCR false negative results. The variations and inconsistency in PCR results could also be due to the use of different animals for detection at different times.

Persistent mortality after ponds became 1-step PCR positive was probably the reason why farmers executed emergency harvests. In farms F9 and F10, the sudden occurrence of 1-step PCR positive results 
without prior 2-step PCR positive results suggests that the possibility of prior 2-step PCR false negative results cannot be ruled out. Although we did not reveal the results of the assays to the farmers during the study, our findings indicate that emergency harvest decisions coincided with shrimp samples turning positive by immunodot test and 1-step PCR. By contrast, farms that yielded immunodot negative and 2-step PCR positive results for WSSV obtained successful harvests. Thus, a transition from immunodot negative to positive could be considered a preset condition for emergency harvest. Based on immunodot assay results, WSSV infection can be divided into 2 stages. Stage 1 includes light infections where immunodot tests are negative and 2-step PCR tests are positive. Stage 2 includes severe infections that yield positive results by immunodot and 1-step PCR. Stage 1 would be equivalent to WSSV levels 3 and 4 and Stage 2 would be equivalent to WSSV levels 1 and 2 as proposed by Lo et al. (1998). Although the total numbers of samples involved in our study were relatively low, our results indicate that obtaining a positive immunodot assay result is as effective as a 1-step PCR result for predicting mass mortalities. In addition, the epidemiological sensitivity and specificity $(100 \%)$ of the immunodot assay for pleopods was identical $(100 \%)$ to that for 1-step PCR for gills. This was higher than the sensitivity and specificity we calculated for the Shrimple test strip (65\% and specificity of $35 \%$, respectively; Powell et al. 2006).

Acknowledgements. Research grants provided by the National Agricultural and Technology Project and Indian Council of Agricultural Research and the Department of Biotechnology, Government of India, New Delhi, are gratefully acknowledged.

\section{LITERATURE CITED}

Anil TM, Shankar KM, Mohan CV (2002) Monoclonal antibodies developed for sensitive detection and comparison of white spot syndrome virus isolates in India. Dis Aquat Org 51:67-75

Editorial responsibility: Timothy Flegel, Bangkok, Thailand
Flegel TW (1997) Major viral diseases of black tiger prawn (P. monodon) in Thailand. World J Microbiol Biotechnol 13:433-442

ICTVdB Management (2006) 00.103.0.01 Whispovirus. In: Büchen-Osmond C (ed) ICTVdB - the universal virus database, version 4. Columbia University, New York, Available online at: www.ncbi.n/m.nih.gov/ICTVdb/ICTVdb

Lightner DV, Redman RM (1998) Shrimp diseases and current diagnostic methods. Aquaculture 164:201-220

Lo CF, Ho CH, Peng SE, Chen CH and others (1996a) White spot syndrome baculovirus (WSBV) detected in cultured and captured shrimps, crabs and other arthropods. Dis Aquat Org 27:215-225

Lo CF, Leu JH, Ho CH, Chen CH and others (1996b) Detection of baculovirus associated with white spot syndrome (WSBV) in penaeid shrimps using polymerase chain reaction. Dis Aquat Org 25:133-141

Lo CF, Chang Y, Cheng C, Kou G (1998) PCR monitoring of cultured shrimp for white spot syndrome virus (WSSV) infection in growout farms. In: Flegel TW (ed) Advances in shrimp biotechnology. National Center for Genetic Engineering and Biotechnology, Bangkok, p 281-286

Nunan LM, Poulos BT, Lightner DV (2000) Use of polymerase chain reaction for the detection of infectious hypodermal and hematopoietic necrosis virus in penaeid shrimp. Mar Biotechnol 2:319-328

Poulos BT, Pantoja CR, Bradley-Dunlop D, Aguilar J, Lightner DV (2001) Development and application of monoclonal antibodies for the detection of white spot syndrome virus of penaeid shrimp. Dis Aquat Org 47:13-23

Powell JWB, Burge EJ, Browdy CL, Shepard EF (2006) Efficiency and sensitivity determination of Shrimple®, an immunochromatographic assay for white spot syndrome virus (WSSV), using quantitative real-time PCR. Aquaculture 257:167-172

Shih HH, Wang CS, Tan LF, Chen SN (2001) Characterisation and application of monoclonal antibodies against white spot syndrome virus. J Fish Dis 24:143-150

Thakur PC, Corsin F, Turnbull JF, Shankar KM and others (2002) Estimation of prevalence of white spot syndrome virus (WSSV) by polymerase chain reaction in Penaeus monodon post-larvae stocked into shrimp farms of Karnataka, India: a population based study. Dis Aquat Org 49:235-243

> Wang SY, Hong C, Lotz JM (1996) Development of a PCR procedure for the detection of Baculovirus penaei in shrimp. Dis Aquat Org 25:123-131

Wang X, Zhan W (2006) Development of an immunochromatographic test to detect white spot syndrome virus of shrimp. Aquaculture 255:196-200

Wang X, Zhan W, Xing J (2006) Development of dotimmunogold filtration assay to detect white spot syndrome virus of shrimp. J Virol Methods 132:212-215

Submitted: October 2, 2006; Accepted: October 26, 2007

Proofs received from author(s): February 29, 2008 